инклюзивного образования. Определено наиболее важные функции учителя во время индивидуализации инклюзивного обучения: стимулирование познавательной деятельности; постоянный контроль за выполнением задач; подбор специальных методов; приемов и средств для учеников с особыми потребностями; своевременная помощь в преодолении трудностей в обучении. Выделены основные коррекционные умения, которыми должен обладать учитель инклюзивного класса начальной иколь. Предложено специальные упражнения для развития учашихся с особыми потребностями.

Ключевые слова: инклюзивное образование, ученики начальной школь, ученики с особыми потребностями, индивидуализачия обучения, индивидуальный подход, психофизические особенности, учебно-познавательная деятельность.

RATUSHNYAK NATALIA. Individualization of inclusive education of primary school students in the system of training future teachers.

The article highlights the problem of preparing future elementary school teachers to organize individualization in inclusive classes. The scientific works of foreign and domestic researchers of this problem are analyzed. The most significant features characterizing an individual approach are highlighted. The structure of the individualization process is presented, in which he formulated the procedural components of individualization and their elements. The basic principle and components of inclusive education are characterized. It was determined that the important functions of a teacher during the individualization of inclusive education are the stimulation of cognitive activity, constant monitoring of tasks, the selection of special methods, techniques and tools for students with special needs, timely assistance in overcoming difficulties in learning. The main correctional skills that a teacher of an inclusive class should have are highlighted. Special exercises are proposed for the development of students with special needs.

Keywords: inclusive education, elementary school students, students with special needs, individualization of education, individual approach, psychophysical features, educational and cognitive activity.

DOI: https://doi.org/10.31392/NZ-npu-145.2019.19

УДК 378. 155.9. 81

Резван О. О., Ільєнко О. Л.

\title{
ПРОБЛЕМА ІМІДЖЕВОГО СПРИЙНЯТТЯ ПРОФЕСІЇ ФІЛОЛОГА У МІЖНАРОДНОМУ ДИСКУРСІ
}

У статті доведено актуальність проблеми іміджевого підходу до професійної діяльності майбутніх перекладачів. Визначено компоненти персонального іміджу перекладача. Досліджено динаміку змісту компонентів поняття “імідж перекладача" у сучасних умовах ринку праці. Доведено вплив на імідж перекладача глобалізачійних прочесів світової економіки. Зауважено про важливість оперативного реагування на запити сучасного суспільства щодо послуг перекладача, зокрема для груп мігрантів. Визначено орієнтири іміджевого підходу підготовки майбутніх перекладачів у закладах вищої освіти.

Ключові слова: філолог, перекладач, імідж, глобалізачія, ринок прачі, професія, послуги. 
Глобалізація всіх галузей економіки, культури, науки привертає увагу суспільства до організації комунікації у міжнародних контактах. Комуніканти, що є представниками різних країн, потребують посередництва у професійному перекладі задля досягнення домовленостей у спеціалізованих сферах. Отже, постать перекладача стає досить важливою стороною економічних стосунків міждержавних відносин, а його образ безпосередньо впливає на враження іноземних партнерів від країни в цілому.

Актуальність дослідження проблеми іміджу перекладача підтверджується результатами опитування студентів фаху 035 “Філогогія" спеціалізація "Германські мови та літератури" (англійська мова). Так, зокрема, було виявлено, що уявлення про власний образ у професії майбутніх перекладачів $€$ досить розмитим. Незважаючи на визначення більшістю опитаних "іміджу" як образу, зокрема у профресії, поняття “імідж перекладача" отримало досить диференційовані змісти: “ознаки оцінювання образу у профресії; стиль перекладу (письма); сукупність характеру, зовнішнього вигляду і освіти; манера перекладання; знання культури інших країн, полімовність, орієнтація у сучасних електронних ресурсах для перекладачів; зібраність, небайдужість; якість перекладів; відгуки працедавців (впливають на розвиток іміджу); суспільна думка про перекладача; рівень кар'єрних досягнень; самопрезентація у професійному товаристві; вишуканість; щось індивідуальне. Отже, зважаючи на важливість фрормування іміджевого підходу до реалізації у професії, вбачаємо необхідність узгодити зміст даного поняття із розумінням його значень у міжнародному дискурсі.

Проблема іміджевого сприйняття професії фрілолога, зокрема перекладача, представлена у науковому дискурсі як цивілізаційна місія, що представляє в цілому імідж держави (С. Тарасова [3], О. Чередниченко [4]), умова ефективної професійної діяльності (Е. Кондратьєв [1]), властивість фрахівця, що позначається на рівні його конкурентності у профресії (О. Мартинюк [2]).

Так, Е. Кондратьєв визначає компоненти персонального іміджу перекладача: об'єктивні зовнішні та фізіологічні властивості особистості (голос та пов'язані із ним інструменти мовлення: тембр, темп; фізіогноміка, міміка, моторика); поведінкові особливості (манера та стиль мовлення, стиль одягу, хода); соціальні та професійні характеристики (освіта, соціальний статус, профресія); самосприйняття у професії; сприйняття референтними групами; публічний образ, створений посередниками (цільовими групами, 3 якими перекладач вступає у безпосередню комунікацію) [1].

Порівняння професії фрілолога-перекладача із іншими близькими за сфрерою діяльності професіями (соціологом, журналістом, фрілологомперекладачем, редактором, копирайтером) дозволило науковцям зробити висновок про те, що саме фрілолог-перекладач уособлює образ держави для іноземних партнерів, впливає на сприйняття ними народу і культури країни. Отже, цікавим виявляється дослідження особливостей іміджевого сприйняття профресії фрілолога-перекладача у міжнародному дискурсі.

Метою статті визначаємо дослідження динаміки змісту компонентів 
поняття “імідж перекладача” у сучасних умовах ринку праці.

Цікавість концепції Е. Кондратьєва щодо змісту іміджу перекладача обумовлена тим, що кожен із компонентів, визначений науковцем, представлений як такий, що може якісно змінюватись, і зміна будь-якого з них впливає на зміну іміджу фахівця в цілому - отже, не можна очікувати, що десь у світі буде два перекладача із якісно однаковим іміджем. Так, найбільш вірогідних змін набувають соціальні та професійні характеристики перекладача, рівень якості яких залежить як від сформованих у процесі професійної діяльності мовних та мовленнєвих компетенцій, так і від розвитку особистісних якостей, що сприяють постійному самовдосконаленню. У зазначеному аспекті погоджуємось із Б. Рубрехтом, який зауважує, що рівень професійності перекладача залежить не стільки від знання ним іноземної мови, скільки від сформованості у нього сили волі, дисципліни, що стають основою вдосконалення професійного продукту - перекладу, досягнення рівня розуміння його усіма людьми [9].

Кардинальних змін щодо іміджевого сприйняття професії перекладача зазнає й соціальний статус професії. Перш за все, це стосується уявлення про конкурентність перекладача, його затребуваність на ринку праці. Слід зазначити, що орієнтація на глобалізацію комунікацій, розвиток технологій дозволяє по-новому підходити до організації діяльності перекладача, який все частіше залишається поза класичним працевлаштуванням. Оскільки перекладацька діяльність $€$ продуктом тимчасового попиту (переклад здійснюється за потребою клієнта), економічно раціональним стає налаштування перекладачів на роботу за фрормою фріланс. У сучасному світі популярності набуває так звана gig economy - система вільного ринку, в якій тимчасові посади є загально прийнятними, а організації укладають контракти 3 незалежними працівниками на короткострокові види робіт. Термін "gig" - це сленгове слово, що означає "робота на визначений проміжок часу" і зазвичай використовується по відношенню до музикантів. Однак до такого формату професійної діяльності цілком правдиво можна віднести й перекладачів. Приклади працівників гіг-економіки можуть включати фрілансерів, незалежних підрядників, працівників на базі проектів та тимчасових працівників або працівників на неповний робочий день.

Тенденція до розвитку гіг-економіки обумовлена (підтверджується) дослідженням компанії Intuit, у якому спрогнозовано, що до 2020 року 40 відсотків американських робітників будуть незалежними підрядниками. Розвиток короткострокових робочих місць має ряд позитивних характеристик. По-перше, в епоху цифрових технологій робоча сила стає все більш мобільною, і роботу все частіше можна проводити з будь-якого місця, так що робота та місце розташування розводяться. Це означає, що фррілансери можуть обирати серед тимчасових робочих місць та проектів у всьому світі, тоді як роботодавці можуть вибирати найкращих людей для конкретних проектів з більшого пулу, ніж наявний у будь-якій галузі.

Розвиток комп'ютерних технологій також безпосередньо сприяв зменшенню кількості робочих місць, оскільки програмне забезпечення заміщає 
деякі види робіт, максимально ефективно використовуючи час. Інші впливи включають фрінансовий тиск на підприємства, що призводить до найму більш гнучкої робочої сили та вступ у виробництво й на ринок праці покоління Міленіуму. Сучасна реальність полягає в тому, що люди прагнуть кілька разів змінювати роботу протягом свого трудового життя, а гіг економіка може розглядатися як еволюція цієї тенденції.

В умовах гіг-економіки бізнес економить ресурси на використання офісних приміщень та навчання персоналу. Бізнес також має можливість укладати договори з експертами для конкретних проектів, послуги яких можуть бути занадто дорогими для найма в якості постійного персоналу. 3 точки зору фррілансера, гіг-економіка може покращити баланс між роботою та життям, що неможливо для більшості робочих місць [7]

Дослідження, проведене в 2016 році Інститутом глобальних досліджень МакКінсі, в якому брали учать 8000 респондентів з США та країн Європи, довело, що 30\% (49 млн.) населення отримують свій основний дохід в галузі гіг-економіки, а 40\% (64 млн.) людей використовують роботу там для отримання додаткового заробітку. Перекладачі в цих країнах зазвичай належать до категорії вільних агентів, тобто вони отримують свій основний дохід від роботи в гіг-економіці.

Перебування в цій категорії приносить переваги. Вільні агенти в усіх галузях промисловості, різних країнах, шо належать до різних вікових категорій, відзначили при опитуванні більшу задоволеність роботою та їі більшу продуктивність. 162 мільйони людей в Європі та США відмовилися від традиційної роботи, щоб продовжити кар'єру в гіг-економіці. Більш високий потенціал заробітку порівняно з багатьма постійними робочими місцями $\epsilon$ ключовою привабливістю, але деякі немонетарні фрактори також входять у список бонусів [11].

Хоча зараз в світі триває дискусія з приводу того, чи зможуть технічні засоби перекладу замінити перекладача, важливим завданням для них та всіх, хто користується перевагами гіг-економіки, $€$ випередження розвитку автоматичних приладів, тобто збереження та розвиток навичок, які неможливо автоматизувати.

Перетворення відбулись і в сприйнятті перекладачів референтними групами. Так, у сучасній організації професійної діяльності перекладача великої ваги набуває їх залученість до соціальних інформаційних платформ, які дозволяють взаємодіяти із потенційними клієнтами та професійною спільнотою.

У сучасному світі перекладачі можуть відправляти виконані завдання 3 цифрових платформ, які з'єднують перекладачів з потенційними клієнтами. Зазвичай це досягається, коли постачальник мовних послуг (LSP) виступає посередником. Тим не менш, перекладачі можуть керувати своїми онлайнпрофрілями та календарями, щоб мати більший контроль над своїм графіком роботи та типом завдань, які вони виконують. Мовні платформи, такі як Language Wire, економлять час та виключають фрінансові витрати на пошук роботи, пропонуючи інструменти, які спрощують співпрацю з бізнесом. 
Асоціація Aquarius сприяє роботі в Інтернеті перекладачів усного та письмового перекладу. У базі даних цього веб-сайту розміщено інформацію про 55599 перекладачів письмового перекладу, 8677 перекладачів усного перекладу, 2811 багатомовних копірайтерів та інших фрахівців з 139 країн [10].

Для пошуків контрактів перекладачі також можуть використовувати вебсайти ProZ.com, TranslatorsCafe.com, а також платформи Hyperlingo, SmartCat, MateCat, TMTown та багато інших.

Щодо розвитку іміджевого компоненту публічного образу, створеного посередниками, велике значення для перекладачів набувають професійні об'єднання, де вони мають можливість підвищити кваліфікацію, отримати важливі знайомства для подальших рекомендацій профресіоналів в профресійних та соціальних мережах. Так, у США активно працюють такі профресійні спільноти перекладачів:

Профресійна спілка лінгвістів США, яка існує з 1943 року, має 1400 членів 3 Північної і Південної Америки, Європи, Азії та Афррики. Основний орган журнал Слово (Word). Спілка спонсорує щорічну лінгвістичну конфреренцію, панельні дискусії з проблем лінгвістики. Запрошені доповідачі $є$ прикладами успішних людей в професії, сприяють створенню іміджу в професії [8];

Американська Асоціація прикладної лінгвістики [5], яка об'єднує вчених 3 50 країн, мета якої, поглиблення і поширення знань з проблем лінгвістики та перекладу;

Ассоціація сертифікованих перекладачів, метою якої $є$ підпримка поваги суспільства до фраху перекладача [6]

Крім зовнішнього представлення професії перекладача, мережеві платфрорми дозволяють визначати, популяризувати та унормовувати профресійні принципи перекладацької спільноти. Так, зокрема, кодекси перекладачів спрямовують фрахівців дотримуватись принципів: професійної солідарності, що виявляється у запобіганні нелояльної конкуренції (цінової політики, умов праці); відповідальності за якість та аутентичність перекладу (незалежно від замовлення клієнта); збереження конфріденційності інформації; дотримання законності авторського права авторів оригінальних текстів тощо. Звісно, що дотримання зазначених принципів впливає як на репутацію окремого перекладача, так і на імідж перекладача в цілому.

Оскільки сучасні перекладачі стають все більшою мірою зорієнтованими на фрріланс, відповідальність за розвиток сфери діяльності набуває характеристики прагматичного аналізу потреб різних суспільних груп. Так, в умовах активізації мігрантських настроїв населення різних країн популярними послугами у сфрері діяльності перекладачів стають:

- переклад юридичних договорів та інших документів для нового бізнесу в зарубіжних країнах; інструкцій;

- переклад інструкцій для працівників, відділів кадрів та робочих

- переклад змісту веб-сайтів та маркетингового контенту;

- переклад особистих документів, професійних журналів;

- усний переклад під час зустрічей, наприклад, працівника із потенційним 
працедавцем;

- двомовна підтримка клієнтів у професійних або приватних контактах.

Резюмуючи аналіз перетворення змісту конкретних компонентів іміджу перекладачів, маємо змогу виокремити конкретні завдання, що стануть орієнтирами для підготовки майбутніх перекладачів у закладах вищої освіти.

Для діяльності в умовах гіг економіки перекладачі мають набувати особистісних якостей: здатності працювати як у команді, так і автономно; мобільності (як реальної, що означає географічні переїзди, так і віртуальної); організованості та дисциплінованості; адаптивності; здатності працювати під впливом; високий рівень комунікативності у міжкультурному просторі; підприємницькі компетенції.

Зважаючи на недостатню відповідність Стандарту з підготовки фрахівця за спеціальністю 035 “Філологія” потребам сучасного ринку праці, а саме відсутності у документі підприємницької компетенції - зауважуємо про необхідність доповнення його змісту згідно з вимогами часу.

Для конкурентоздатності на ринку праці перекладачі мають навчитись працювати з сучасними програмними продуктами (різного роду словниками), а також із законодавчими та нормативними джерелами.

Для розвитку у студентів підприємницьких компетенцій слід осучаснити педагогічні підходи до організації навчальної діяльності студентів та змісту занять. Ефективним для досягнення зазначеної мети вважаємо створення мотиваційних словників; вивчення досвіду видатних перекладачів; організацію зустрічей з представниками фрірм-посередників з надання перекладацьких послуг; проведення практик в агенціях з перекладу; обговорення ділових інтерв'ю; створення документів, необхідних для працевлаштування; підготовка професійних профрілів для електронних платформ; ознайомлення з методами пошуку клієнтів; проведення рейтингування праці перекладача; спрямування студентів на рефлексію та самооцінку рівня власної готовності до діяльності в умовах сучасного ринку праці.

Крім того, необхідним вважаємо проведення тренінгів 3 проектного менеджменту (упорядкування плану роботи, створення фрінансової заявки, здійснення поетапного планування, оцінки проекту, створення звіту за проектом), оскільки зазначені навички є необхідними для роботи в умовах гіг економіки. Необхідно навчати студентів орієнтуватись у ринку фрінансових пропозицій на послуги перекладу (різних його видів, умов та строків виконання), а також у питаннях авторського права та юридичної реєстрації приватного підприємництва.

Важливим вважаємо орієнтацію майбутніх перекладачів на вступ до профресійних спілок фрілологів та перекладачів України, активну реєстрацію та користування електронними професійними мережами, зокрема Linkedin.

\section{Використана література:}

1. Кондратьев Э. В., Абрамов Р. Н. Связи с общественностью. Москва : Академический Проект, 2004. $432 \mathrm{c}$. 
2. Мартинюк О. В. Проблеми професійної підготовки перекладачів у педагогічних дослідженнях вітчизняних та зарубіжних науковців. [Ел. ресурс]. Режим доступу : https://www.narodnaosvita.kiev.ua/Narodna_osvita/vupysku/15/statti/martinuk.htm

3. Тарасова С. О. Маска-імідж у англомовному політичному дискурсі. Вісник ХНУ імені B. Н. Каразіна. Серія: Іноземна філологія. Методика викладання іноземних мов, (84), С. 136-142.

4. Чередниченко О. Із виступу на III академічній дискусії “Націєтворча місія перекладу” проекту Інституту філології Київського національного університету імені Тараса Шевченка та фонду “Свропа XXI" - "Українська гуманітаристика. Діалог культур між Сходом і Заходом". [Ел. pecypc]. Режим доступу : https://www.radiosvoboda.org/a/24182705.html

5. American Association for Applied Linguistics [Electronic resource]. Available at: https://www.aaal.org/

6. American Translators Association [Electronic resource]. Available at: https://www.atanet.org/

7. Gig economy [Electronic resource]. Available at: https://whatis.techtarget.com/definition/gig-economy

8. International Linguistic Association [Electronic resource]. Available at: https://hallidaycentre.cityu.edu.hk:2443/ila/05_lectures_2018-2019.aspx

9. Rubrecht Brian G. Knowing Before Learning: Ten concepts students should understand prior to enrolling in a university translation or interpretation class [Електронний pecypc]. Translation Journal. 2005. Vol. 9. No. 2. Режим доступу : http://translationjournal.net/journal//32edu.htm.

10. The La-La Land of Translation Marketplaces [Electronic resource]. Available at: https://massardo.com/blog/translation-marketplaces/

11. Translation and the gig economy : How technology is changing the game [Electronic resource]. Available at: https://www.languagewire.com/en/lw/themes/gig-economy

\section{References:}

[1] Kondratev E. V., Abramov R. N. (2004) Svyazi s obshestvennostyu. Moskva : Akademicheskij Proekt. $432 \mathrm{~s}$.

[2] Martyniuk O. V. Problemy profesiinoi pidhotovky perekladachiv u pedahohichnykh doslidzhenniakh vitchyznianykh ta zarubizhnykh naukovtsiv. [El. resurs]. Rezhym dostupu : https://www.narodnaosvita.kiev.ua/Narodna_osvita/vupysku/15/statti/martinuk.htm

[3] Tarasova S. O. Maska-imidzh u anhlomovnomu politychnomu dyskursi. Visnyk KhNU imeni V. N. Karazina. Seriia: Inozemna filolohiia. Metodyka vykladannia inozemnykh mov, (84), S. 136-142.

[4] Cherednychenko O. Iz vystupu na III akademichnii dyskusii "Natsiietvorcha misiia perekladu" proektu Instytutu filolohii Kyivskoho natsionalnoho universytetu imeni Tarasa Shevchenka ta fondu "Ievropa XXI" - "Ukrainska humanitarystyka. Dialoh kultur mizh Skhodom i Zakhodom". [El. resurs]. Rezhym dostupu : https://www.radiosvoboda.org/a/24182705.html

[5] American Association for Applied Linguistics [Electronic resource]. Available at: https://www.aaal.org/

[6] American Translators Association [Electronic resource]. Available at: https://www.atanet.org/

[7] Gig economy [Electronic resource]. Available at: https://whatis.techtarget.com/definition/gig-economy

[8] International Linguistic Association [Electronic resource]. Available at: https://hallidaycentre.cityu.edu.hk:2443/ila/05_lectures_2018-2019.aspx

[9] Rubrecht Brian G. Knowing Before Learning: Ten concepts students should understand prior to enrolling in a university translation or interpretation class [Elektronnyi resurs]. Translation Journal. 2005. Vol. 9. No. 2. Rezhym dostupu : http://translationjournal.net/journal//32edu.htm.

[10] The La-La Land of Translation Marketplaces [Electronic resource]. Available at: https://massardo.com/blog/translation-marketplaces/

[11] Translation and the gig economy : How technology is changing the game [Electronic resource]. Available at: https://www.languagewire.com/en/lw/themes/gig-economy

\section{РЕЗВАН О. О., ІЛЬЕНКО О. Л. Проблема Имиджевого восприятия профессии филолога в международном дискурсе. \\ В статье доказана актуальность проблемы имиджевого подхода к профессиональной} деятельности будущих переводчиков. Определень компоненты персонального имиджа переводчика. Исследована динамика содержания компонентов понятия "имидж переводчика" в современных условиях рынка труда. Доказано влияние на имидж переводчика прочессов глобализаций мировой экономики. Отмечена важность оперативного реагирования на запросы 
современного общества относительно услуг переводчика, в частности для групп мигрантов. Определены ориентиры имиджевого подхода подготовки будущих переводчиков в высших учебных заведениях.

Ключевые слова: филолог, переводчик, имидж, глобализация, рынок труда, профессия, услуги.

REZVAN O., ILIENKOO. The problem of image perception of the profession of philologist in international discourse.

The topicality of the problem of image approach to the professional activities of future translators is proved in the article. The components of the personal image of the translator are identified: objective external and physiological properties of the personality (voice and related speech instruments: the pitch of the voice, the tempo of speech; physiognomy, facial expressions, movements); behavioral characteristics (manner and style of speech, style of clothing, walking); social and professional characteristics (education, social status, profession); self-perception in the profession; perception by reference groups; public image created by mediators (target groups which the translator communicates with). The dynamics of the content components for the concept "image of the translator" in modern conditions of the labor market is investigated. The influence of globalization processes of the world economy on the image of the translator is proved, in particular, the need to work in the conditions of the gig economy. The need for translators' virtual mobility is emphasized through an active use of electronic professional networking platforms, for instance, Linkedin. The importance of responding promptly to modern society's requests for translation services, in particular for migrant groups, is registered. The guidelines for the image approach of preparation of future translators at higher education institutions are defined and the specific tasks for supplementing the content of the academic training due to the professional standard 035 "Philology" are outlined. services.

Keywords: philologist, translator, interpreter, image, globalization, labor market, profession,

DOI: https://doi.org/10.31392/NZ-npu-145.2019.20

УДК 027.1:929

Савенкова Л. В., Торлін І. Г.

\section{ПРИВАТНА БІБЛІОТЕКА ВЧЕНОГО ЯК ДОДАТКОВЕ ДЖЕРЕЛО ВІДТВОРЕННЯ ЙОГО ТВОРЧОЇ БІОГРАФІї}

Дослідження наукової спадщини науковиів є важливою складової вивчення історії будьякого університету. У підготовленому матеріалі представлені результати дослідження особистого зібрання відомого фізика, професора, очільника кафедри фізики Київського педагогічного інституту імені М. Горького з 1934 до 1947 року Г. Г. Де-Метияа, які дозволяють відстежсити наукові зв'зки вченого у першій половині 20-го століття.

Ключові слова: дослідження, джерела, наука, історія, життєвий шлях.

Документальні джерела $є$ важливою базою для наукових досліджень у будь якій науковій галузі. Вивчення культурних та наукових досягнень кожної країни змушує звертатись до книжкових пам'яток, серед яких вагомою 